\title{
PERHITUNGAN GT KAPAL IKAN BERDASARKAN PERATURAN DI INDONESIA DAN PEMODELAN KAPAL DENGAN DIBANTU KOMPUTER (STUDI KASUS KAPAL IKAN MUNCAR DAN PRIGI)
}

\author{
Gross Tonnage Calculation on Fishing Vessels Based on Indonesian Regulation and A \\ Computer Aided Modeling (Case Study of Fishing Vessels in Muncar And Prigi)
}

Oleh:

Sunardi ${ }^{*}$, Achmad Baidowi², Eko Sulkhani $Y^{3}$

\author{
${ }^{1}$ Fakultas Perikanan dan Ilmu Kelautan, Universitas Brawijaya, Malang, Indonesia.sunardi@ub.ac.id \\ ${ }^{2}$ Fakultas Teknologi Kelautan, Institut Tekhnologi Sepuluh Nopember, Surabaya, Indonesia. ahmadbai@gmail.com \\ ${ }^{3}$ Fakultas Perikanan dan Ilmu Kelautan, Universitas Brawijaya, Malang, Indonesia. ekosulkhaniy@ub.ac.id \\ *Korespondensi: sunardi@ub.ac.id
}

\begin{abstract}
A gross tonnage (GT) is a volume capacity of fishing vessel regarding its role in the fisheries resource utilization and management affairs. Information regarding GT is important, hence there is a need to conduct measurement in objective manner. The result of GT recalculation conducted by the Ministry of Transportation on under 30 GT fishing vessels showed that there is a significant difference between the documented GT and recalculated GT which indicates a massive mark down. Consequently, most of owners decline the later result as it goes higher and has impact on operational cost. Regarding that problem, this paper investigates the GT calculation process in Indonesia. In order to provide objective measurement, this research compares the existing GT calculation method and numerical computation. The result reveals that both methods produced different GT, which is about 32\% gap for fishing vessels in Muncar and 27\% gap in Prigi.
\end{abstract}

Keywords: Gross tonnage, fishing boat, measurement, numerical computation

\begin{abstract}
ABSTRAK
Gross tonnage (GT) merupakan suatu ukuran yang menunjukkan besarnya volume kapal untuk menampung hasil dari operasi penangkapan ikan dalam rangka pemanfaatan sumberdaya perikanan. Mengingat pentingnya data tentang ukuran kapal ikan dan banyaknya stakeholder yang memerlukan data ini, maka penting untuk dilakukan kajian tentang pengukuran GT kapal ikan secara obyektif. Hasil penertiban pada ukuran kapal ikan dibawah 30 GT menunjukkan bahwa terdapat perbedaan yang signifikan antara GT kapal sebelum dan sesudah pengukuran ulang oleh Kementerian Perhubungan. Akibatnya, sebagian nelayan menolak hasil pengukuran tersebut, karena angka yang lebih tinggi daripada sebelumnya akan berdampak pada peningkatan biaya operasional kapal. Penelitian ini akan menelusuri bagaimana proses perhitungan GT kapal ikan di Indonesia dilakukan. Untuk memberikan penilaian yang lebih obyektif, perhitungan GT yang dihasilkan dari metode yang berlaku secara nasional dibandingkan dengan metode pemodelan komputer. Hasil perhitungan untuk kedua metode menunjukkan perbedaan dengan selisih GT 32\% untuk kapal ikan di Muncar dan $27 \%$ untuk kapal ikan di Prigi.
\end{abstract}

Kata kunci: Gross tonnage, kapal ikan, pengukuran, pemodelan komputer 


\section{PENDAHULUAN}

Pemerintah Indonesia melalui Kementerian Kelautan dan Perikanan (KKP) dan Kementerian Perhubungan (KEMENHUB) sedang giat melakukan pendataan kapal untuk mengetahui secara pasti kapasitas usaha perikanan tangkap yang beroperasi di Indonesia dan untuk menertibkan kapal ikan yang beroperasi di Indonesia. Puluhan kapal di Indramayu, Cirebon dan Sukabumi melakukan mark down ukuran kapal ikan yaitu GT kapal ikan lebih kecil dari pada sebenarnya setelah dilakukan pengukuran ulang (Yulianto 2016). Sebagian besar pengukuran ulang yang dilakukan oleh Departemen Perhubungan Laut melalui Kesyahbandaran dan Otoritas Pelabuhan (KSOP) menunjukan sebagian besar kapal melakukan mark down dari ukuran kapal sebenarnya. Data hasil pengukuran GT kapal ikan sebelum dan sesudah pengukuran ulang yang dilakukan oleh Kementerian Perhubungan Republik Indonesia di Jakarta untuk kapal ikan di Jakarta dengan ukuran awal kurang dari 30 GT sangat berbeda dengan perbedaan rata-rata mencapai $111 \%$ antara selisih pengukuran ukuran GT yang baru dan lama (Sutjasta 2018). Berdasarkan hasil kajian tersebut, menunjukkan bahwa perbedaan ukuran GT sebelum dan sesudah pengukuran berkisar antara 10-67 GT, dengan rata-rata 32,2 GT. Hasil pengukuran ulang menunjukkan bahwa ukuran GT kapal setelah pengukuran ulang lebih besar dibandingkan dengan ukuran GT kapal sebelum pengukuran ulang kapal.

Perbedaan nilai GT ini menyebabkan terjadinya banyak penolakan terhadap pengukuran ulang kapal ikan, karena sebagian besar nelayan merasa dirugikan dari segi kebijakan, perijinan, biaya labuh, jatah mendapatkan bahan bakar bersubsidi dan lain sebagainya. Perhitungan ukuran GT kapal ikan oleh pemerintah digunakan sebagai:

1. Pengaturan kewenangan perizinan dan pungutan perikanan (PP RI no. 62 tahun 2002)

2. Penentuan daerah penangkapan ikan (PP RI no. 62 tahun 2002)

3. Pemberian IUP, SPI, SIKPI pada kapal ikan (PP RI no. 62 tahun 2002)

4. Kewenangan pemberian perijinan kapal ikan (PP RI no. 54 tahun 2002)

5. Penentuan jalur-jalur penangkapan ikan (Kepmentan No. 92/KPTS/lk.120/99)

6. Penataan perijinan kapal ikan asing (Kepment Kelautan dan Perikanan No. KEP/38/MEN/2003

Mengingat sangat besar pengaruhnya untuk nelayan dan stakeholder terkait tentang data ukuran GT kapal ini, maka penelitian ini perlu dilakukan dengan tujuan untuk menelusuri metode pengukuran GT kapal di Indonesia dan membandingkan hasil pengukuran GT kapal yang berlaku di Indonesia dengan pengukuran GT menggunakan model komputer.

\section{METODE}

Pelaksanaan penelitian dilakukan di Muncar dan Prigi untuk pengambilan data penelitian. Pengolahan data dilakukan di Laboratorium Marine Manufacturing and Design, Institut Teknologi Sepuluh Nopember (ITS) dan Laboratorium Teknologi Penangkapan Ikan, Universitas Brawijaya pada bulan juni 2018 .

Metode yang digunakan dalam penelitian ini adalah metode deskriptif kuantitatif dari pendekatan perhitungan GT untuk metode perhitungan kapal ikan dalam negeri menurut Permenhub No.8 Tahun 2013 dan metode perhitungan internasional (international convention on tonnage measurement of ships tahun 1969) serta metode perhitungan dengan dibantu komputer (berlisensi) untuk mendapatkan nilai $\mathrm{Cb}$ yang tepat. Pemodelan dengan dibantu komputer dilakukan di Laboratorium Marine Manufacturing and Design, Institut Teknologi Sepuluh Nopember (ITS).

Data yang dibutuhkan dalam penelitian ini adalah data ukuran kapal yang didapatkan dari hasil pengukuran secara langsung. Data ini berikutnya digunakan untuk menghitung GT kapal ikan berdasarkan peraturan perhitungan kapal dalam negeri dan perhitungan GT dengan pendekatan pemodelan kapal dibantu komputer.

Subyek penelitian adalah kapal penangkap ikan di PPN Muncar, Banyuwangi dan PPN Prigi, Trenggalek. Peralatan yang digunakan adalah alat ukur yang digunakan untuk mengukur kapal dan personal computer yang dilengkapi dengan software Microsoft Office 2010 dan aplikasi Maxsurf).

Jenis data yang dibutuhkan meliputi data dimensi utama kapal serta lebar dan tinggi badan kapal dari tiap titik-titik pengukuran tertentu yang ditetapkan berdasarkan metode sympson's. Data tersebut diperoleh melalui pengukuran langsung terhadap objek/kapal yang diteliti yaitu sampel kapal di Muncar, Banyuwangi dan sampel kapal di Prigi. Data sekunder diambil melalui SIUP/SIPI kapal. Sebagai penelitian awal, data primer didapatkan dari pengukuran masing-masing satu kapal ikan di dua lokasi yaitu di Muncar dan Prigi pada bulan Juni tahun 2018. Sampel kapal diambil hanya satu pada setiap lokasi dengan pertimbangan bahwa desain dan produksi kapal untuk satu jenis kapal ikan yang diambil dalam 
penelitian ini bentuknya sangat mirip. Metode pembuatan kapal yang sama, bentuk lambung yang sama, maka "nilai kelangsingan/kegemukan" atau Cb kapal akan tidak jauh berbeda untuk satu jenis kapal di suatu daerah. Pengamatan di lapangan menunjukkan bentuk kapal sangat mirip, namun ukuran kapal cukup variatif.

Pengolahan data perhitungan GT kapal ikan kecil (kapal dengan ukuran dibawah 24 meter) dapat dilakukan dengan metode dalam negeri atau metode internasional atas permintaan pemilik kapal (Permenhub No.8 Tahun 2013). Metode pengukuran GT dalam negeri adalah (Keputusan Direktorat Jenderal Perhubungan Laut Nomor PY.67/1/13-90 pasal 24 ayat (2)):

$G T=0,25 \times V$

dengan:

0,25 = Merupakan koefisien berdasarkan Keputusan Direktorat Jenderal Perhubungan Laut Nomor PY.67/1/13-90 pasal 24 ayat (2).

$V=$ Jumlah volume ruangan di bawah geladak ukur ditambah dengan jumlah volume ruangan di atas geladak yang tertutup sempurna dan berukuran tidak kurang $1 \mathrm{~m} 3$.

Rumus yang digunakan dalam metode pengukuran GT dalam negeri untuk menghitung volume di bawah geladak adalah:

$V=L \times B \times D \times f$

dengan:

$L=$ Panjang kapal, diukur dari geladak yang terdapat di belakang linggi haluan sampai geladak yang terdapat di depan linggi buritan secara mendatar, panjang ini sering disebut dengan panjang geladak ukur.

$B=$ Lebar kapal, adalah jarak mendatar diukur antara kedua sisi luar kulit lambung kapal pada tempat yang terbesar, tidak termasuk pisang-pisang. Hal ini karena metode pengukuran dalam negeri mengasumsikan bahwa kapal-kapal di Indonesia secara umum terbuat dari kayu.

$D=$ Tinggi kapal, adalah jarak tegak lurus di tempat yang terlebar, diukur dari sisi bawah gading dasar sampai sisi bawah geladak sampai pada ketinggian khayal yang melintang melalui sisi atas dari lambung tetap.

$f=$ Faktor, di dalam metode pengukuran dalam negeri ini faktor ditentukan berdasarkan bentuk lambung atau jenis kapal, yaitu:
- 0,85 bagi kapal-kapal dengan bentuk penampang penuh atau bagi kapal dengan dasar rata, secara umum digunakan bagi kapal tongkang.

- 0,70 bagi kapal-kapal, dengan bentuk penampang hampir penuh atau dengan dasar agak miring dari tengah-tengah ke sisi kapal, secara umum digunakan untuk kapal motor.

- 0,50 bagi kapal-kapal yang tidak termasuk golongan (1) dan (2) secara umum digunakan bagi kapal layar atau kapal layar yang dibantu motor.

Menghitung volume bangunan di atas ruang geladak yang meliputi rumah geladak, kepala palka, dan sebagainya dapat diperoleh dengan cara mengalikan panjang dengan lebar dengan tinggi ruangan atau dalam bentuk rumus: Volume ruangan bangunan $=p x / x t$. Bangunan tertutup di atas geladak termasuk kepala palka yang volumenya kurang dari $1 \mathrm{~m} 3$ (satu meter kubik), tidak dimasukkan dalam perhitungan untuk menetapkan GT. Selanjutya perhitungan GT dengan metode dalam negeri adalah memasukkan variabel $L, B, D$ yang merupakan hasil pengukuran kapal dan nilai $f$ berdasarkan bentuk lambungnya.

Pengolahan data untuk pemodelan kapal dengan dibantu komputer dilakukan dengan memodelkan bentuk kapal sebenarnya ke dalam model komputer dengan data yang didapatkan dari hasil pengukuran ke dalam aplikasi desain kapal dibantu komputer untuk kemudian dicari nilai coefficient of block (Cb) kapal hasil pemodelan dan selanjutnya dijadikan dasar dalam perhitungan GT kapal berdasarkan pemodelan. Kapal nelayan Muncar (Banyuwangi) dan Prigi (Trenggalek) di ukur, di foto untuk mendapatkan bentuk dan ukuran utama lambung kapal. Selanjutnya dimodelkan bentuk lambung kapal dengan bantuan aplikasi Maxsurf sesuai dengan kapal sebenarnya. Bentuk lambung kapal selanjutnya dianalisis untuk mendapatkan parameter hidrostatis yang salah satu parameter yang ada adalah koefisien bentuk kapal atau Coefficient of Block (Cb). Nilai $\mathrm{Cb}$ ini yang dijadikan salah satu variabel utama untuk melakukan perhitungan GT selanjutnya dengan menggunakan persamaan yang berlaku. Sehingga dapat dikatakan bahwa pengukuran GT kapal dengan melalui pemodelan kapal, tidak menggunakan nilai "f" sebagaimana yang ditetapkan dalam Keputusan Direktorat Jenderal Perhubungan Laut Nomor PY.67/1/13-90 pasal 24 ayat (2). Akan tetapi menggunakan nilai $\mathrm{Cb}$ yang merupakan representasi dari dimensi dan bentuk kasko kapal itu sendiri. Hal ini dikarenakan nilai $\mathrm{Cb}$ adalah rasio antara volume badan 
kapal di bawah dek dengan perkalian panjang, lebar dan tinggi kapal (Fyson 1985).

Aplikasi desain kapal yang digunakan dalam penelitian ini adalah Maxsurf, yang terbukti cukup handal untuk membentuk lambung kapal, melakukan perhitungan komputasi numerik untuk kapal tentang tahanan kapal, stabilitas kapal, hidrostatis kapal, sistem propulsi kapal dan sebagainya (Ahmed 2012; Prayitno 2012; Susanto 2012; Luasunaung 2013; Amriardi 2016).

Analisis data dilakukan dengan membandingkan nilai pengukuran GT kapal di bawah 24 meter dari 3 pendekatan: 1) Metode perhitungan GT yang diterapkan saat ini, menurut Permenhub No.8 Tahun 2013; 2) Metode perhitungan Internasional untuk ukuran kapal lebih dari 24 meter, 3) Metode pemodelan kapal ikan dengan ukuran dibawah 24 meter dengan dibantu komputer. Kenyataan di lapangan, pengukuran GT kapal kecil yang tertera di SIUP dan SIPI menggunakan metode dalam negeri, meskipun dalam peraturan yang berlaku membolehkan pemilik kapal kecil mengajukan pengukuran kapal dengan metode internasional. Untuk analisis data, perbandingan hasil pengukuran GT yang digunakan hanya dua yaitu perhitungan dengan metode dalam negeri dan metode pemodelan dengan komputer.

\section{HASIL}

Tahapan pemodelan kapal ikan menggunakan komputer dengan aplikasi maxsurf adalah pemodelan kapal dari hasil pengukuran kapal yang terdiri dari data ukuran utama kapal, data lebar kapal setiap jarak gading dari buritan sampai haluan, foto kapal ikan tampak samping dan depan untuk kemudian diverifikasi pada pemilik kapal. Tujuan pemodelan kapal ini adalah untuk mendapatkan bentuk dan ukuran kapal yang sesuai dengan kapal sebenarnya. Selanjutnya model kapal ini dianalisis untuk memperoleh nilai parameter hidrostatis dari sampel kapal ikan Muncar, Banyuwangi dan Kapal ikan Prigi, Trenggalek yang dijadikan obyek penelitian.

\section{a. Kapal Ikan di Muncar, Banyuwangi}

Kapal ikan yang dijadikan sampel untuk lokasi Muncar, Banyuwangi merupakan kapal ikan untuk operasi penangkapan ikan dengan menggunakan alat tangkap purse seine. Dimensi utama kapal purse seine di Muncar, Banyuwangi adalah sebagai berikut:

- $L O A=20$ meter

- Lebar $(B)=6$ meter

- Tinggi dek $(D)=1,45$ meter

\section{$L($ pada saat $D=1,45$ meter $)=18,6$ meter}

Secara umum kapal purse seine di PPN Muncar, Banyuwangi memiliki bentuk lambung roundbottom, dan tenaga penggerak adalah jenis mesin tempel. Volume ruang kapal yang diteliti terdiri dari 16 ruang yang terdiri dari; ruang jacket pelampung, ruang jangkar, ruang rumpon, ruang palka, ruang bahan bakar, dan ruang peralatan mesin. General arrangement kapal ikan Muncar tampak seperti pada Gambar 1 dan 2.

Parameter hidrostatis diperoleh melalui penggambaran model, dimana nilai-nilai berasal dari hasil pengukuran. Nilai parameter hidrostatis inilah yang selanjutnya digunakan untuk menentukan nilai GT dari suatu kapal. Gambar hasil pemodelan menggunakan aplikasi maxsurf disajikan pada Gambar 3, 4, 5 dan 6, sedangkan nilai dari parameter hidrostatis disajikan pada Tabel 1.

Gambar 3, 4, 5 dan 6 merupakan gambar pemodelan lambung kapal yang dibuat berdasarkan hasil pengukuran sebelumnya. Bentuk lambung kapal dimodelkan semirip mungkin dengan kapal sebenarnya, meskipun belum sangat presisi $100 \%$. Perhitungan GT Kapal ikan yang mengacu pada volume ruang muat, sehingga $\mathrm{Cb}$ diukur dengan mengabaikan lunas dan linggi haluan kapal (Gambar 6). Jika linggi dan lunas kapal disertakan, maka nilai $\mathrm{Cb}$ kapal akan semakin kecil. Nilai perhitungan hidrostatis purse seine Muncar, Banyuwangi (lunas dan linggi kapal tidak diperhitungkan) disajikan pada Tabel 1.

Nilai $\mathrm{Cb}$ kapal ikan Muncar, Banyuwangi seperti pada Tabel 1 adalah 0,53, dengan mengambil ukuran kapal di atas lunas dan linggi kapal:

$$
\begin{aligned}
& L=16,74 \text { meter } \\
& B=5,8 \text { meter } \\
& D=1,25 \text { meter (diatas lunas kapal) } \\
& L \times B \times D=142,3 \mathrm{~m}^{3}
\end{aligned}
$$

Perbedaan nilai GT antara hasil pemodelan kapal (1) dengan hasil pengukuran metode GT dalam negeri (2) adalah sebagai berikut:

$$
\begin{aligned}
\text { 1. GT } & =0,25 \times L \times B \times D \times 0,53 \\
& \text { (Nilai Cb hasil pemodelan kapa) } \\
= & 0,25 \times 142,3 \times 0,53 \\
& =18,8 \mathrm{GT} \\
\text { 2. GT } & =0,25 \times L \times B \times D \times 0,7 \\
& \text { (nilai } f(0,7) \text { untuk kapal bermotor dan } \\
& \text { bentuk lambung agak miring dari tengah } \\
& \text { ke sisi kapal) } \\
& =0,25 \times 142,3 \times 0,7 \\
& =24,9 \mathrm{GT} \text { hasil pemodelan kapal }
\end{aligned}
$$

Selisih perhitungan $=6,1$ GT atau $32 \%$ lebih besar daripada nilai GT kapal dengan metode perhitungan pemodelan kapal. 


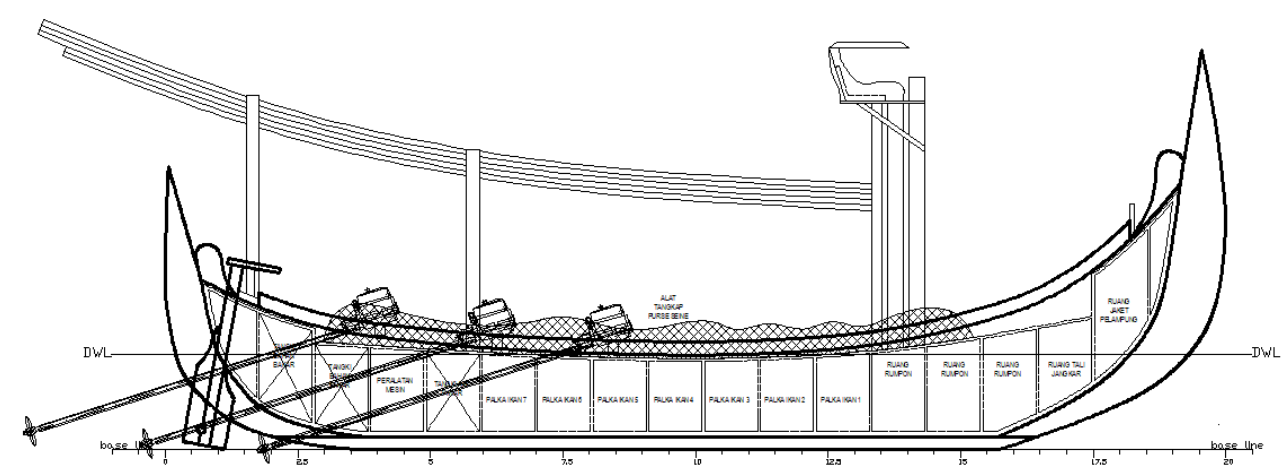

Gambar 1 Kapal ikan Muncar tampak samping

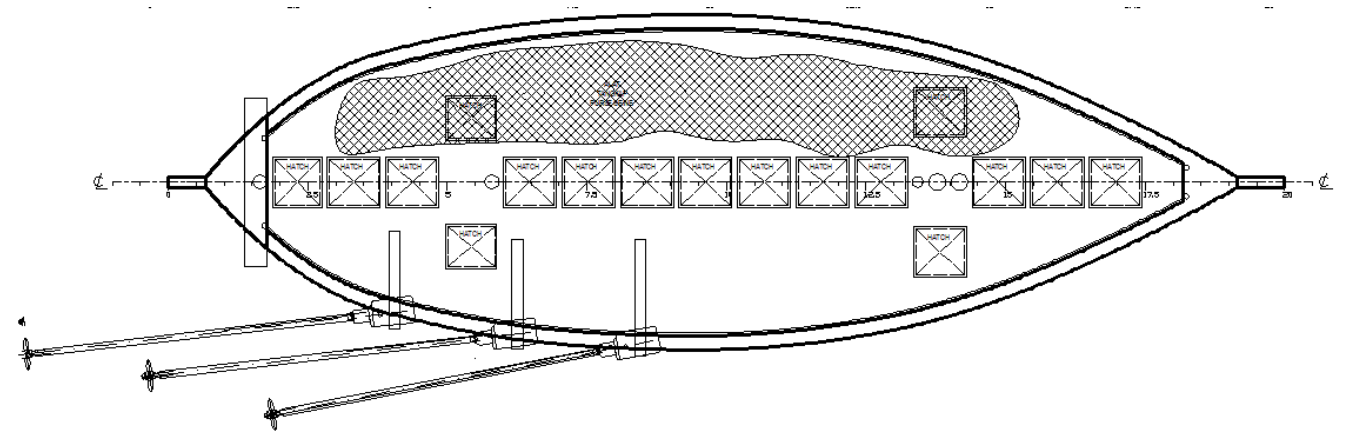

Gambar 2 Kapal ikan Muncar tampak atas

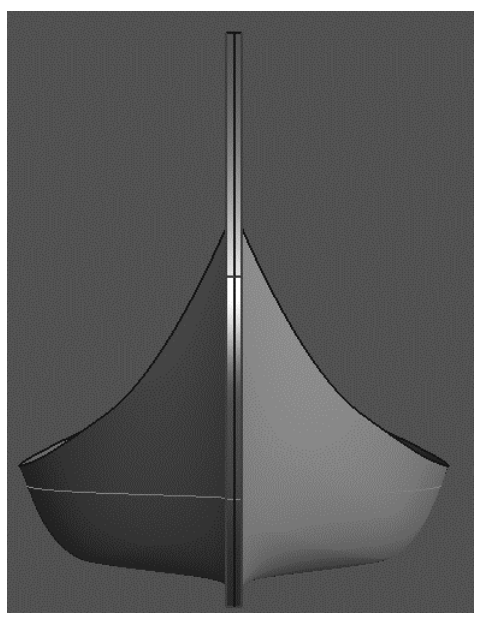

Gambar 3 Pemodelan dengan komputer kapal ikan Muncar tampak depan

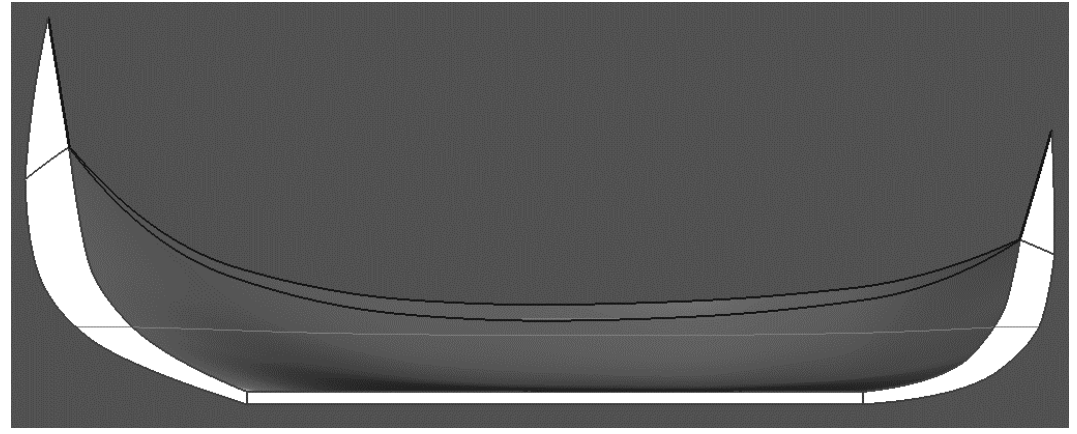

Gambar 4 Pemodelan dengan komputer kapal ikan Muncar tampaksamping 


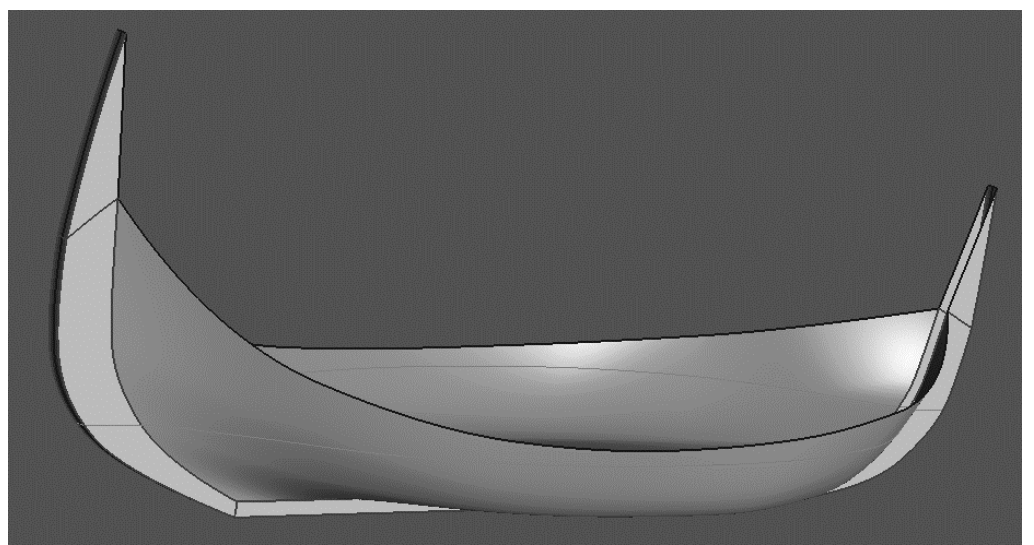

Gambar 5 Pemodelan dengan komputer kapal ikan Muncar tampak perspective

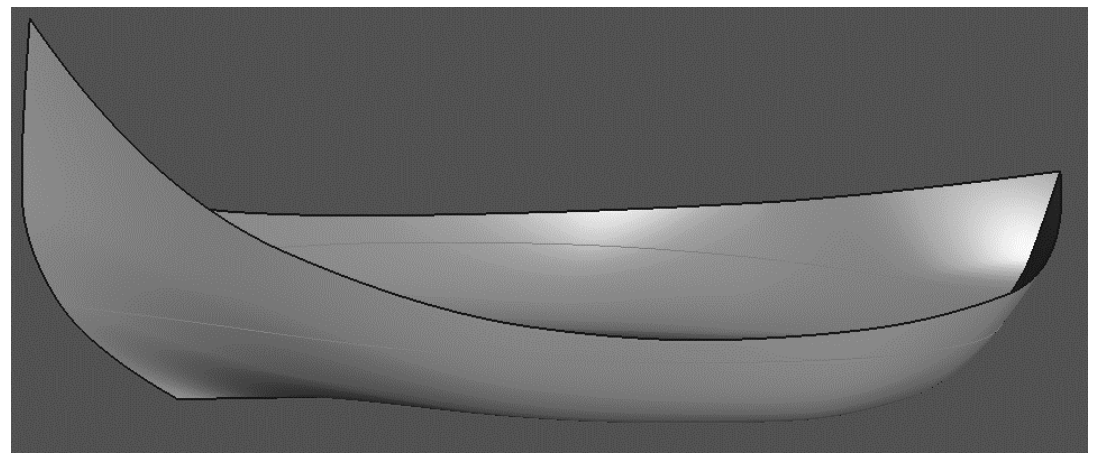

Gambar 6 Pemodelan dengan komputer kapal ikan Muncar tampak perspective (lunas dan linggi dihilangkan)

Tabel 2 Nilai parameter hidrostatis kapal ikan purse seine Muncar, Banyuwangi

\begin{tabular}{|c|c|c|}
\hline Perhitungan & Nilai & Satuan \\
\hline Displacement & 66,09 & ton \\
\hline Volume (displaced) & 64,47 & $\mathrm{~m}^{3}$ \\
\hline Draft Amidships & 1,25 & $\mathrm{M}$ \\
\hline Immersed depth & 1,25 & M \\
\hline WL Length & 16,736 & M \\
\hline Beam max extents on $W L$ & 5,808 & M \\
\hline Wetted Area & 87,139 & $\mathrm{~m}^{2}$ \\
\hline Max sect. area & 6,101 & $\mathrm{~m}^{2}$ \\
\hline Waterpl. Area & 68,817 & $\mathrm{~m}^{2}$ \\
\hline Prismatic coeff. $(C p)$ & 0,631 & \\
\hline Block coeff. (Cb) & 0,531 & \\
\hline
\end{tabular}

\section{b. Kapal Ikan di Prigi Trenggalek}

Kapal ikan yang dijadikan sampel untuk lokasi Prigi, Trenggalek merupakan kapal ikan untuk operasi penangkapan ikan menggunakan alat tangkap purse seine. Dimensi utama kapal purse seine di Prigi, Trenggalek adalah sebagai berikut :

- LOA $=15$ meter

- $B=5$ meter

- $\mathrm{D}=1,25$ meter
Secara umum kapal purse seine di PPN Prigi, Trenggalek bertipe single hull bagian belakang dengan bentuk lambung roundbottom, dan tenaga penggerak adalah jenis inboard engine. Volume ruang kapal sampel yang diteliti, terdiri dari 13 ruang yang terdiri dari: ruang perbekalan, ruang jangkar, ruang palka, ruang bahan bakar, dan ruang peralatan mesin. General arrangement disampaikan pada Gambar 7 dan 8. 
Parameter hidrostatis diperoleh melalui penggambaran model berdasarkan hasil pengukuran kapal yang sesungguhnya. Nilai parameter hidrostatis inilah yang selanjutnya digunakan untuk menentukan nilai GT dari suatu kapal. Gambar hasil pemodelan menggunakan aplikasi maxsurf disajikan pada Gambar 9, 10, 11 dan 12 , sedangkan nilai dari parameter hidrostatis disajikan pada Tabel 2. Hasil perhitungan hidrostatis kapal ikan Prigi (lunas dihilangkan) disajikan pada Tabel 2.

Nilai $\mathrm{Cb}$ seperti tampak pada Tabel 2 untuk kapal Prigi berdasarkan pemodelan kapal adalah 0,55 , dengan mengambil ukuran kapal di atas lunas dan linggi kapal:
$\mathrm{L}=12,8$ meter
$\mathrm{B}=4,65$ meter
$\mathrm{D}=1$ meter (di atas lunas kapal)
$\mathrm{L} \times \mathrm{B} \times \mathrm{D}=60 \mathrm{~m}^{3}$

Perbedaan nilai GT antara hasil model dengan hasil pengukuran metode GT dalam negeri adalah sebagai berikut:

$$
\text { 1. GT } \begin{aligned}
& =0,25 \times L \times B \times D \times 0,55 \\
& \text { (nilai Cb hasil pemodelan kapa) } \\
& =0,25 \times 60 \times 0,55 \\
& =8,25 \mathrm{GT}
\end{aligned}
$$

\section{2. $G T=0,25 \times L \times B \times D \times 0,7$}

(nilai $f=0,7$ untuk kapal bermotor dan bentuk lambung agak miring dari tengah ke sisi kapal)

$=0,25 \times 60 \times 0,7$

$=10,5 \mathrm{GT}$

Selisih perhitungan $=2.25$ GT atau $27 \%$ lebih besar daripada nilai GT kapal dengan metode perhitungan pemodelan kapal.

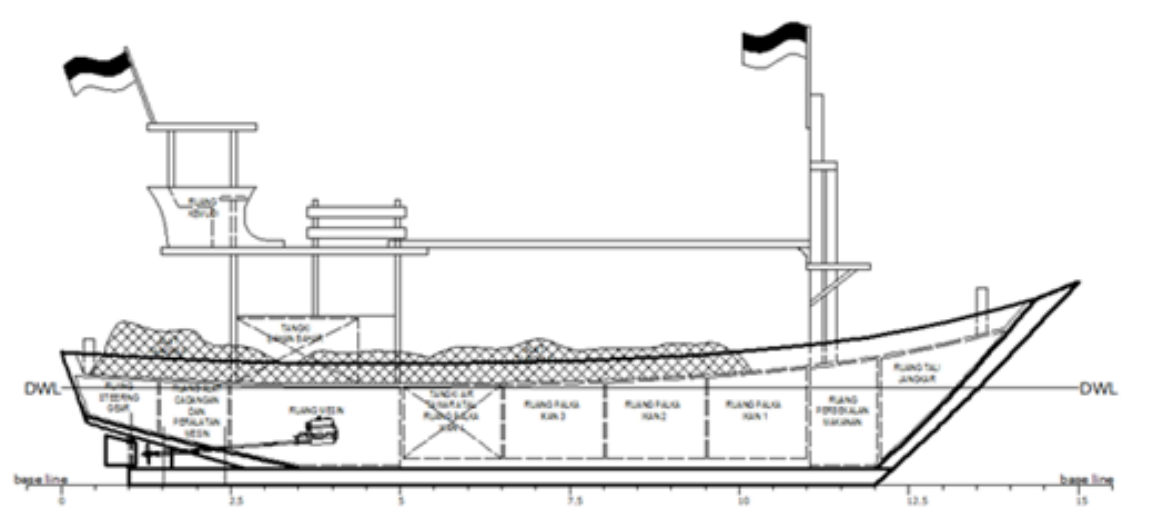

Gambar 7 Kapal ikan Prigi tampak samping

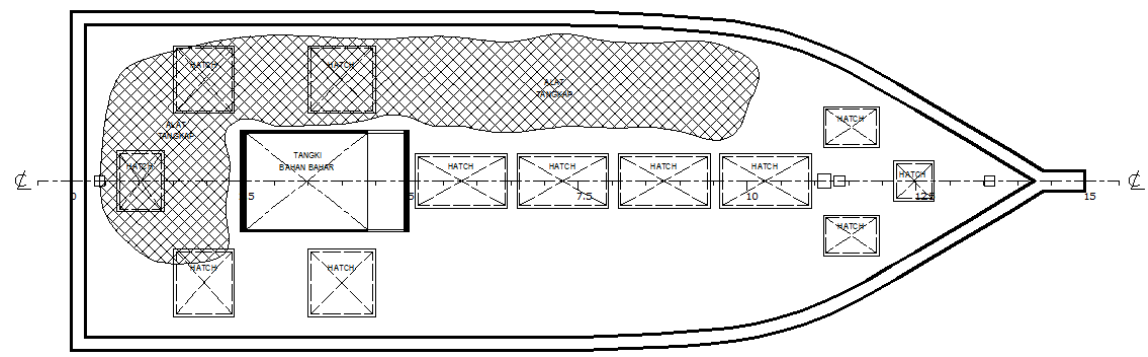

Gambar 8 Kapal ikan Prigi tampak atas

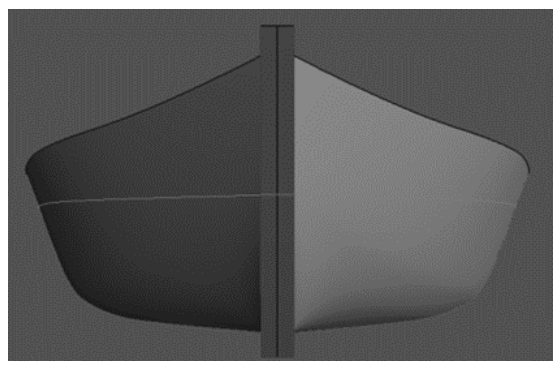

Gambar 9 Pemodelan dengan komputer tampak depan 


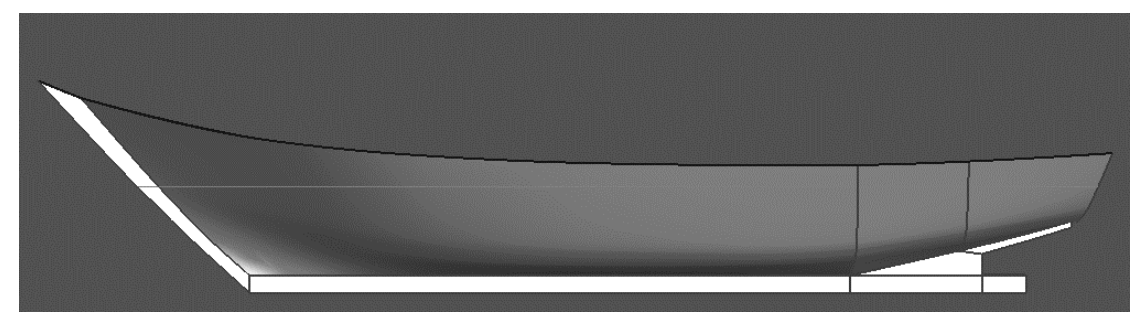

Gambar 10 Pemodelan dengan komputer tampak samping

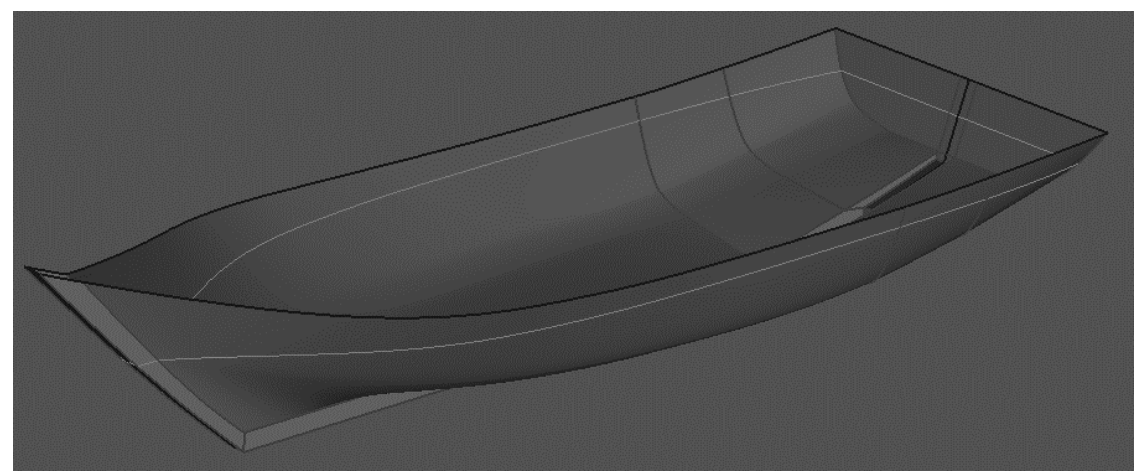

Gambar 11 Pemodelan dengan komputer tampak perspective

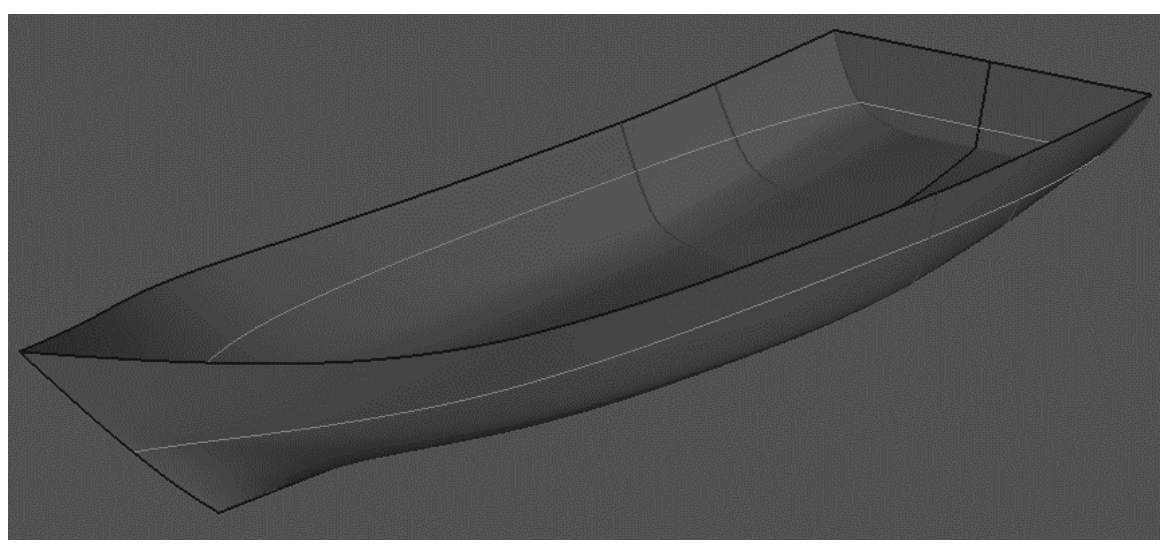

Gambar 12 Pemodelan dengan komputer tampak perspective (tanpa lunas)

Tabel 2 Nilai parameter hidrostatis kapal ikan purse seine Prigi, Trenggalek

\begin{tabular}{|c|c|c|}
\hline Perhitungan & Nilai & Satuan \\
\hline Displacement & 33,79 & ton \\
\hline Volume (displaced) & 32,96 & $\mathrm{~m}^{3}$ \\
\hline Draft Amidships & 1 & $\mathrm{~m}$ \\
\hline Immersed depth & 1 & $\mathrm{~m}$ \\
\hline WL Length & 12,789 & $\mathrm{~m}$ \\
\hline Beam max extents on $W L$ & 4,651 & $\mathrm{M}$ \\
\hline Wetted Area & 59,349 & $\mathrm{~m}^{2}$ \\
\hline Max sect. area & 3,833 & $\mathrm{~m}^{2}$ \\
\hline Waterpl. Area & 49,192 & $\mathrm{~m}^{2}$ \\
\hline Prismatic coeff. (Cp) & 0,672 & \\
\hline Block coeff. $(\mathrm{Cb})$ & 0,554 & \\
\hline
\end{tabular}




\section{PEMBAHASAN}

Berdasarkan persamaan dalam perhitungan GT kapal, terdapat beberapa variabel yang menentukan atau berpengaruh terhadap besaran nilai GT dari suatu kapal yaitu diantaranya; 1) keputusan pengambilan nilai 0,25 dan $\mathrm{k}_{1}$ sebagai pengali perhitungan GT, dan 2) keputusan dalam pengambilan nilai f untuk perhitungan GT kapal ikan.

\section{Nilai 0,25 dan $k_{1}$ sebagai Pengali Perhi- tungan GT}

Pengambilan nilai 0,25 dan $\mathrm{k}_{1}$ sebagai pengali perhitungan GT dalam perhitungan GT suatu kapal tidak terlalu berpengaruh signifikan terhadap besaran nilai GT suatu kapal ikan. Metode perhitungan GT dalam negeri menggunakan 0,25 sebagai pengali $V$ untuk perhitungan GT, sedangkan metode internasional menggunakan $\mathrm{k}_{1}$ sebagai pengali $\mathrm{V}$ dengan nilai $\mathrm{k}_{1}=0.2$ $+0.02 \log \mathrm{V}$. Mengacu dari data Organisasi Internasional Konservasi Ikan di Lautan Pasific (WCPFC, 2014), GT kapal Indonesia terkecil di lautan Pacific dengan GT rata-rata 76.9 GT. Jika kita mengambil ukuran volume kapal ikan tradisional di Indonesia yang diukur antara $10 \mathrm{~m}^{3}$ (sekitar 2,5 GT) sampai dengan $1000 \mathrm{~m}^{3}$ (sekitar $250 \mathrm{GT}$ ), maka nilai $\mathrm{k}_{1}$ antara 0.22 dan 0.26 .

$k_{1}=0.2+0.02 \log V$

untuk $\mathrm{V}=10 \mathrm{~m}^{3}, \mathrm{k}_{1}=0.22$

untuk $\mathrm{V}=10.000 \mathrm{~m}^{3}, \mathrm{k}_{1}=0.28$

Selisih perhitungan dengan nilai 0,25 untuk perhitungan GT kapal ikan hanya sekitar \pm $3 \%$ dari total GT dengan range volume kapal $1 \overline{0}$ $\mathrm{m}^{3}$ sampai dengan $10.000 \mathrm{~m}^{3}$. Dengan demikian jika diberi pilihan untuk memilih menggunakan metode dalam negeri atau luar negeri untuk kapal dibawah 24 meter, maka sebagai pemilik kapal jika perhitungan volume kapal tertutup kurang dari $315 \mathrm{~m}^{3}$, lebih baik memilih perhitungan Internasional karena pengali $\mathrm{V}$, yaitu $(0.2$ + $0.02 \log$ V) kurang dari 0.25.

Nilai $\mathrm{k}_{1}$ untuk $\mathrm{V}=315 \mathrm{~m}^{3}$ adalah

$\mathrm{k}_{1}=0.2+0.02 \log 315 \mathrm{~m}^{3}=0,25$ (nilai tepat 0,25 )

Jika volume kapal kurang dari $315 \mathrm{~m}^{3}$, maka nilai $k_{1}$ akan lebih kecil lagi daripada 0,25 (pengali pengukuran GT dalam negeri), dengan asumsi metode perhitungan volume ruang tertutupnya hasilnya sama.

\section{Faktor "f" pada Perhitungan GT Kapal Ikan Berdasarkan Permenhub No.8 Tahun 2013.}

Pengambilan nilai "f" berdampak pada besaran nilai GT yang signifikan. Perhitungan GT Kapal Ikan dengan metode dalam negeri GT=
$0,25 \times \mathrm{V}$, dimana $V=L \times B \times D \times f$. Pengambilan keputusan nilai $f$ akan sangat besar pengaruhnya terhadap hasil perhtungan GT. Nilai $f$ yang digunakan oleh Departemen Perhubungan untuk pengukuran GT kapal ikan:

- 0,85 bagi kapal-kapal dengan bentuk penampang penuh atau bagi kapal dengan dasar rata, secara umum digunakan bagi kapal tongkang.

- 0,70 bagi kapal-kapal, dengan bentuk penampang hampir penuh atau dengan dasar agak miring dari tengah-tengah ke sisi kapal, secara umum digunakan untuk kapal motor.

- 0,50 bagi kapal-kapal yang tidak termasuk golongan (1) dan (2) secara umum digunakan bagi kapal layar atau kapal layar yang dibantu motor.

Dengan nilai $f$ tersebut diatas, maka beberapa hal penting sebagai catatan adalah:

- tidak ada kapal ikan dengan bentuk tongkang $(f=0.85)$

- hampir tidak ada kapal ikan yang menggunakan layar pada saat ini $(\mathfrak{f}=0.5)$

- semua perhitungan GT pada kapal ikan menggunakan $f=0.7$, karena hanya ada 3 pilihan yaitu 0,5, 0,7 atau 0,85.

\section{Perhitungan GT Kapal lkan dengan Pemodelan Dibantu Komputer}

Perbedaan utama dalam perhitungan GT kapal ikan dengan pemodelan secara komputerisasi dengan perhitungan menurut Permenhub No.8 Tahun 2013 adalah dalam menentukan nilai koefisien. Penghitungan volume kapal sebagai dasar perhitungan GT kapal ikan, jika pada Permenhub No 8 Tahun 2013; koefisien " $f$ " ditetapkan hanya 3 nilai dengan definisi tertentu sebagaimana telah dijabarkan sebelumnya. Akan tetapi dalam perhitungan GT kapal ikan dengan cara pemodelan, koefisien " $f$ " yang digunakan adalah nilai $\mathrm{Cb}$ kapal. $\mathrm{Cb}$ adalah nilai dari Coefficien of block yang diperoleh dari hasil pemodelan kapal ikan dengan dibantu komputer. Coefficien of block (Cb) merupakan koefisien bentuk kapal, perbandingan antara volume bidang lengkung kapal dengan volume balok (LxBxD), seperti ilustrasi Gambar 13.

$G T=0,25 \times V$

$V=L \times B \times D \times C b$

Besaran nilai $\mathrm{Cb}$ sangat ditentukan oleh dimensi kapal dan bentuk kapal itu sendiri. Sehingga nilai $\mathrm{Cb}$ sangat bervariasi dan spesifik untuk dimensi dan bentuk kasko tertentu. Lain halnya dengan koefisien " $\mathrm{f}$ " yang ditetapkan dalam Permenhub No 8 Tahun 2013, dimana setiap kapal yang akan diperhitungkan GT -nya, hanya dapat memilih satu dari tiga nilai koefisien 


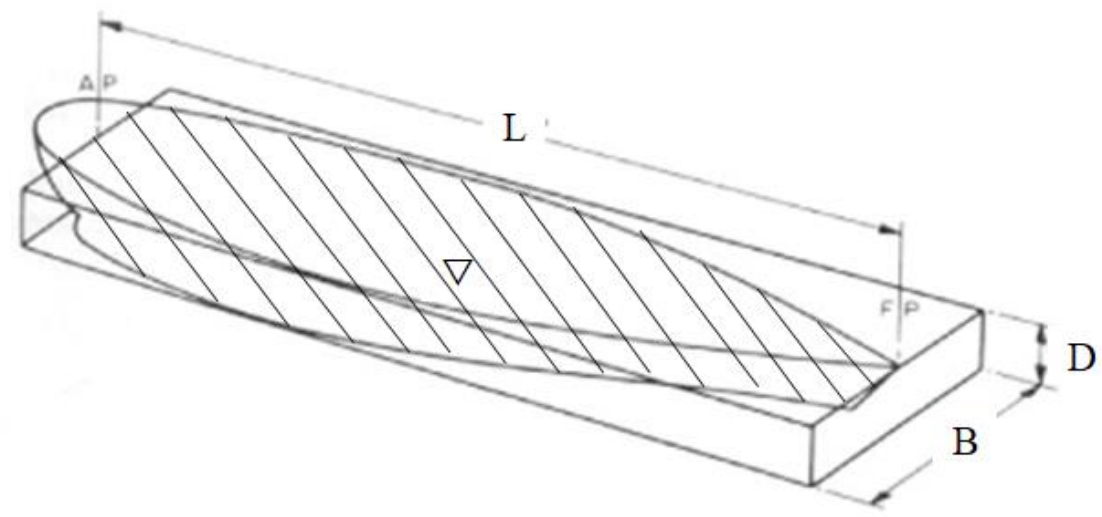

Gambar 13 Koefisien Block (CB) suatu kapal (Fyson 1985)

yang telah ditetapkan. Hal ini bertentangan dengan kondisi bentuk kasko kapal ikan di Indonesia, dimana menurut Rouf dan Novita (2006) menyebutkan bahwa bentuk kasko ikan diantaranya adalah berbentuk U-bottom, hardchin bottom, round bottom, round flat bottom, dan akatsuki bottom.

GT adalah suatu ukuran volume kapal, maka perhitungan untuk menghitung volume kapal dengan pengali $\mathrm{Cb}$ adalah sangat tepat. Nilai Cb kapal ikan menurut penelitian Iskandar dan Pujiati dalam Nanda 2004 terbagi menjadi beberapa kategori; 1) Kapal ikan yang mengoperasikan alat tangkap dengan melingkarkan mempunyai nilai $\mathrm{Cb}$ antara 0,56 - 0,67; 2); kapal ikan dengan alat tangkap statis nilai $\mathrm{Cb}$ berkisar 0,39 - 0,7; dan 3); dan kapal ikan dengan alat tangkap ditarik, nlai $\mathrm{Cb}$ berkisar antara 0,4 - 0,6.

Beberapa referensi kapal ikan tentang $\mathrm{Cb}$ kapal ikan di berbagai negara nilainya antara 0,5 sampai dengan 0,6 (Obreja 2010; Tello 2010; dan Thomas 2010). Vietnam mengambil nilai $\mathrm{Cb}$ = 0,6 untuk pengukuran GT kapal ikan di negara tersebut (Kawata 2016). Penelitian di dalam negeri dengan sampel kapal ikan di beberapa lokasi menunjukkan nilai $\mathrm{Cb}$ lebih kecil dari itu, $\mathrm{Cb}=0,389$ untuk kapal ikan purse seine di Kabupaten Pinrang (Aziz 2017). Kapal ikan di Cilacap memiliki nilai $\mathrm{Cb}=0,52$ (Amriadi 2016) dan kapal ikan purse seine tradisional di Sulawesi utara nilai $\mathrm{Cb}$ antara 0,35 - 0,43 (Manopo 2012).

\section{Perbedaan Perhitungan GT Kapal Ikan dengan Permenhub No.8 Tahun 2013 dan Pemodelan Dibantu Komputer}

Pengambilan nilai "f" pada perhitungan dengan Permenhub No.8 Tahun 2013 dan nilai $\mathrm{Cb}$ untuk perhitungan GT dengan pemodelan komputer, nilai GT kapal mempunyai selisih $32 \%$ untuk satu hasil pengukuran pada kapal ikan purse seine di Muncar dan 27\% untuk pengu- kuran 1 unit kapal ikan purse seine di Prigi. Mengacu pada penjelasan nilai "f" yang menunjukkan jenis dan bentuk lambung kapal, pertimbangan utama dalam penentuan faktor " $f$ " ini pasti faktor kelangsingan/kegemukan kapal, yang identik dengan nilai $\mathrm{Cb}$ suatu kapal. Pengambilan nilai $f=0,7$ sebagai pengali dalam perhitungan GT kapal ikan di Indonesia sangat besar kemungkinan kesalahannya, karena bentuk kapal ikan yang ada di Indonesia sangat bervariasi.

\section{Dampak dari Kesalahan Perhitungan GT Kapal Ikan}

Dampak yang ditimbulkan dari kemungkinan kesalahan pengukuran ini adalah semua ketentuan, peraturan terkait perijinan operasi penangkapan, biaya tambat labuh, daerah penangkapan dan sebagainya yang sangat berbeda, terutama untuk ukuran kapal ikan di bawah $30 \mathrm{GT}$ dan di atas $30 \mathrm{GT}$. Dampak lainnya adalah besarnya biaya yang dikeluarkan nelayan baik dalam pungutan pengusahaan perikanan (PPP) Baru atau Perubahan, dimana besarannya adalah Rp 41.650/GT untuk purse seine kecil ataupun pungutan hasil perikanan (PHP) yang sangat tergantung dari besaran GT kapal ikan sebagai pengalinya. Besaran PHP adalah 5\% x Produktivitas kapal x Harga Patokan Ikan x Ukuran GT Kapal. Perbedaan besaran GT berimplikasi pada nelayan terutama dari segi kebijakan, perijinan, biaya labuh, jatah mendapatkan bahan bakar, dan hal tersebut berpengaruh pada produktivitas mereka. Seperti yang diungkapkan Muhammad et al. (2018) yang menyatakan bahwa peningkatan produktivitas dapat dilakukan dengan pengurangan jumlah nelayan, pengurangan BBM dan es pendingin. Hal sama juga diungkapkan Tawari et al. (2014), bahwa kendala yang dihadapi armada penangkapan nelayan skala kecil yang beroperasi di Seram Bagian Barat salah satunya adalah ukuran kapal, jarak tempuh, penggunaan bahan bakar mi- 
nyak (BBM), penggunaan es, biaya akomodasi dan alat tangkap.

\section{KESIMPULAN}

Pengambilan faktor pengali ( $f$ atau $\mathrm{Cb}$ ) pada pengukuran GT kapal ikan di bawah panjang 24 meter merupakan titik kritis yang menentukan ketepatan hasil pengukuran. Pengambilan faktor pengali 0,7 untuk menghitung sebagian besar GT kapal ikan perlu dibuktikan lebih lanjut untuk mendapatkan faktor pengali yang tepat untuk setiap kapal ikan. Hasil pemodelan 2 kapal di Muncar dan di Prigi dengan aplikasi dibantu komputer mendapatkan hasil yang berbeda dengan ketentuan PERMENHUB No 8 tahun 2013 dengan selisih hasil perhitungan GT 32\% untuk kapal ikan di Muncar dan 27\% untuk kapal ikan di Prigi.

\section{SARAN}

Perlu adanya kajian akademis untuk pengukuran GT kapal ikan, perhitungan pendekatan yang dilakukan saat ini masih sangat kasar dimana faktor pengali "f" sama dengan 0,7 berlaku untuk hampir semua kapal ikan. Padahal bentuk kapal ikan untuk berbagai jenis kapal ikan di setiap lokasi wilayah pengelolaan perikanan (WPP) sangat bervariasi.

\section{UCAPAN TERIMA KASIH}

Terima kasih kepada nelayan di Muncar, Banyuwangi dan Prigi, Trenggalek. Laboratorium Marine Manufacturing and Design, Institut Teknologi Sepuluh Nopember (ITS) dan Laboratorium Teknologi Penangkapan FPIK Universitas Brawijaya.

\section{DAFTAR PUSTAKA}

Ahmed YM, Jamail AB, Yaakob OB. 2012. Boat Survey Using Photogrammetry Method. Int Rev Mech Eng. 6(7): 1643-1647.

Amriardi U, Samuel S, Iqbal M. 2016. Analisa Hambatan Kapal Ikan Tradisional Catamaran di Perairan Cilacap karena Perubahan Bentuk Lambung dengan Pendekatan Lattice Boltzmann Method (Lbm). Jurnal Teknik Perkapalan. 4(1): 20-27.

Aziz MA, Iskandar BH, Novita Y. 2017. Kajian Desain Kapal Purse Seine Tradisional di Kabupaten Pinrang (Study Kasus KM. Cahaya Arafah). Albacore. 1(1): 69-76.
Fyson J. 1985. Design of Small Fishing Vessels. England. Fishing News Book. Pages: 21-53.

Kawata T, Thanasansakorn S, Miyoshi J. 2016. Research and Analysis of Hull form of Small Fishing Vessels in Southeast Asia. Techno-Ocean. 2016: 264-267.

Luasunaung A, Pangalila FP. 2013. Kajian Rancang Bangun Kapal Ikan Fibreglass Multifungsi 13 GT di Galangan Kapal CV Cipta Bahari Nusantara Minahasa Sulawesi Utara. Jurnal IImu dan Teknologi Perikanan Tangkap. 1(3): 87-92.

Manopo AR, Masengi KW, Pamikiran RDC. 2012. Studi Pengaruh Bentuk Kasko pada Tahanan Kapal Pukat Cincin di Tumumpa, Bitung, dan Molibagu (Provinsi Sulawesi Utara). Jurnal IImu dan Teknologi Perikanan Tangkap. 1(2): 63-68.

Muhammad AH, Paroka D, Rahman S, Syarifuddin. 2018. Tingkat Kelayakan Operasional Kapal Perikanan 30 GT pada Perairan Sulawesi (Studi Kasus KM Inka Mina 957). Marine Fisheries Journal. 9(1): 1-9.

Nanda A. 2004. Pengukuran dan Penggunaan GT Kapal Ikan di Indonesia. [skripsi]. Bogor: Institut Pertanian Bogor.

Obreja D, Nabergoj R, Crudu L, PăcuraruPopoiu S. 2010. Identification of Hydrodynamic Coefficients for Manoeuvring Simulation Model of a Fishing Vessel. Ocean Engineering. 37(8-9): 678687.

PERMENHUB RI No. 8 Tahun 2013 Tentang Pengukuran Kapal. [Internet]. [download 2018 July 30]. Can be access on: http://jdih.dephub.go.id/assets/uudocs/pe rmen /2013/pm.8_tahun_2013.pdf

PERMENKP No 38 Tahun 2015 tentang Tata Cara Pemungutan Penerimaan Negara Bukan Pajak Pada Kementerian Kelautan dan Perikanan Yang Berasal Dari Pungutan Perikanan. [Internet]. [download 2018 July 28]. Can be access on http://jdih.kkp.go.id/peraturan /38\%20PERMEN-KP\%202015.pdf.

Prayitno MME. 2012. Analisa Teknis Optimalisasi Sistem Propulsi Kapal Ikan Menggunakan CVT Gearbox. Kapal. 9(3): 116122.

Rouf ARA, Novita Y. 2006. Studi Tentang Bentuk Kasko Kapal Ikan di Beberapa Daerah di Indonesia. Jurnal Torani. 4(16): 51-62. 
Sudjasta B, Suranto PJ, Putra CES. 2018. Analisis Pengukuran Ulang Tonage Kapal Penangkap Ikan dengan Panjang Kurang dari 24 Meter. Bina Teknika Jurnal. 14(1): 79-85.

Susanto A, Iskandar BH, Imron M. 2012. Stabilitas Statis Kapal Static Gear di Palabuhanratu (Studi Kasus KM PSP 01). Marine Fisheries: Journal of Marine Fisheries Technology and Management. 2(1): 6573.

Tawari RHS., Simbolon D, Purbayanto A, Taurusman AA. 2014. Analisis Optimasi Armada Penangkapan Madidihang Skala Kecil di Kabupaten Seram Bagian Barat. Marine Fisheries Journal. 5(2): 129-137.

Tello M, e Silva SR, Soares CG. 2011. Seakeeping Performance of Fishing Vessels in Irregular Waves. Ocean Engineering. 38(5-6): 763-773.
Thomas G, O'doherty D, Sterling D, Chin C. 2010. Energy Audit of Fishing Vessels. Proceedings of the Institution of Mechanical Engineers, Part M: Journal of Engineering for the Maritime Environment. 224(2): 87-101.

WCPFC. 2014. Conservation and Management Measure for Standards, Specifications and Procedures for the Record of Fishing Vessels. [Internet]. [download 2018 December 8]. Can be access on https://www.wcpfc.int/doc/cmm-201403/standards-specifications-andprocedures-western-and-central-pacificfisheries.

Yulianto A. 2016. 51 Unit Kapal Nelayan Mark Down Bobot. [Internet]. [download 2019 Januari 8]. Can be access on https://www.republika.co.id/berita/koran/n ews-update/16/03/14/o40x4m 16-51- nitkapal-nelayan-mark-down-bobot. 